\title{
Kamila Żyło
}

Katedra Filmu i Mediów Audiowizualnych

Uniwersytet Łódzki

\section{NOWE SZATY KRÓLA. REKONESANS STANU BADAŃ NAD NARRACJĄ FILMOWA W POLSCE}

Badania narratologiczne na gruncie rodzimego filmoznawstwa wydają się i to po raz kolejny - przechodzić falę wzmożonego zainteresowania, czego świadectwem jest kilka opublikowanych w ciągu ostatnich dwóch lat książek. Dwie podejmują temat bezpośrednio, choć $\mathrm{z}$ różnych perspektyw oraz $\mathrm{w}$ różnych ujęciach (monografie Jacka Ostaszewskiego i Roberta Birkholca) $)^{1}$, trzy kolejne oscylują w dużej mierze wokół narracji, nawet jeśli pozornie zogniskowane są na zagadnieniach poetyki czy stylu (propozycje Rafała Syski, Barbary Szczekały, Andrzeja Zalewskiego) ${ }^{2}$.

J. Ostaszewski, Historia narracji filmowej, Universitas, Kraków 2018; R. Birkholc, Podwójna perspektywa. O subiektywizacji zapośredniczonej w filmie, Universitas, Kraków 2019.

2 R. Syska, Filmowy neomodernizm, Wydawnictwo Avalon, Kraków 2014; B. Szczekała, Mind-game films. Gry z narracją $i$ widzem, Narodowe Centrum Kultury Filmowej, Łódź 2018; A. Zalewski, Strategiczna dezorientacja. Perypetie rozumu $w$ fabularnym filmie postmodernistycznym, Instytut Kultury, Warszawa 1998.
Publikacje te stanowią pretekst do spojrzenia wstecz oraz przypomnienia kilku wcześniejszych pozycji (zarówno książek, jak i artykułów) poświęconych narracji filmowej, a stanowiących niejednokrotnie interesujące, autorskie propozycje - w Polsce nieco zapomniane, a badaczom spoza kraju niedostępne, bo niepublikowane w języku angielskim. Rodzima narratologia filmoznawcza ma wielu przedstawicieli. Warto zacząć od nazwisk badaczy, których wkład w jej rozwój jest szczególnie istotny, a więc Andrzeja Zalewskiego ${ }^{3}$, Tomasza Kły-

Na uwagę zasługują już teksty Andrzeja Zalewskiego z końca lat siedemdziesiątych i osiemdziesiątych, które czerpią z dziedzictwa fenomenologii ontologicznej (zwłaszcza koncepcji Romana Ingardena) jako punktu wyjścia. W myśl ustaleń myślicieli tego nurtu filozoficznego, skupionego na przedmiocie, jego sens konstytuowany jest $\mathrm{w}$ procesie odbioru. Znaczenie struktury estetycznej rodzi się w akcie lektury, nigdy w oderwaniu od niej. Zalewski przejmuje te przekonania i to one zbliżają go do kognitywistów. Ich echa odnaleźć można w dotyczącej przede wszystkim fikcji literackich książce Dyskurs w narracji fikcjonalnej, jak i opublikowanym w „Kinie” artykule Typy 
$\mathrm{sa}^{4}$ oraz Mirosława Przylipiaka ${ }^{5}$ i Jacka Ostaszewskiego ${ }^{6}$, a także przypomnieć

konstrukcji znaczeniowych w filmie - próba analizy fenomenologicznej. Zob. A. Zalewski, Dyskurs w narracji fikcjonalnej, Zakład Narodowy im. Ossolińskich - Wydawnictwo Polskiej Akademii Nauk, Wrocław-Warszawa-Kraków-Gdańsk-Łódź 1988; idem, Typy konstrukcji znaczeniowych w filmie - próba analizy fenomenologicznej, „Kino” 1979, nr 161, s. 27.

4 Książka Tomasza Kłysa Film fikcji i jego dominanty (Semper, Warszawa 1999) jest jedną z pierwszych rozpraw, która przybliżyła polskiemu czytelnikowi narracje z perspektywy kognitywistycznej.

5 W poniższym tekście nie omówię klasycznej na gruncie polskiego filmoznawstwa książki Mirosława Przylipiaka Kino stylu zerowego. Z Zagadnień estetyki filmu fabularnego (Gdańskie Wydawnictwo Psychologiczne, Gdańsk 1994) i jej wydanej po latach, zaktualizowanej edycji Kino stylu zerowego. Dwadzieścia lat później (Gdańskie Wydawnictwo Psychologiczne, Gdańsk 2018). Publikacja ta ma bowiem charakter podręcznikowy, nie przedstawia koncepcji autorskiej, ponadto podejmuje zagadnienia związane z narracją w ograniczonym zakresie (tej dotyczą rozdziały drugi: Kino opowiada historię, oraz trzeci: Styl zerowy).

6 Mirosława Przylipiaka i Jacka Ostaszewskiego uznaję za najważniejszych przedstawicieli narratologii w polskim filmoznawstwie nie tylko ze względu na ich autorski wkład w tę dziedzinę badań, który będę szerzej omawiała w tekście, ale także ze względu na działania służące rozpowszechnianiu i systematyzowaniu wiedzy o tym ,jak film opowiada". Warto przypomnieć, że Przylipiak jest autorem haseł „fabuła” i ,narracja” w Stowniku pojęć filmowych (M. Przylipiak, Narracja, w: A. Helman, Słownik pojęć filmowych, t. 5, Wiedza o Kulturze, Wrocław 1993; idem, Fabuła, w: A. Helman, Stownik pojęć filmowych, t. 7, Wiedza o Kulturze, Wrocław 1994), z kolei Ostaszewski wprowadził do polskiej narratologii filmoznawczej i upowszechnił kognitywizm (J. Ostaszewski, Film i poznanie. Wprowadze- kilka rozproszonych artykułów, po które dziś sięga garstka specjalistów. W poniższym tekście w największym zakresie skupię się na najnowszej propozycji dotyczącej narracji filmowej, napisanej przez wrocławskiego uczonego Roberta Birkholca książce Podwójna perspektywa. O subiektywizacji zapośredniczonej $w$ filmie. Jest to publikacja, która właśnie się ukazała na rynku wydawniczym, a jednocześnie bez wątpienia pozostaje symptomatyczna dla polskiego filmoznawstwa, kontynuuje bowiem jego tradycje i podpiera koncepcje teoretyczne wnikliwymi analizami. Zacznę jednak od rekonstrukcji przełomu w historii narratologii, narratologii nie bez przyczyny kojarzonej przede wszystkim z obszarem badań literaturoznawczych, oraz od wskazania ścieżek, jakie wyznaczyła ona polskiemu filmoznawstwu. W tym wypadku postaram się nakreślić najważniejsze tendencje i kierunki rozwojowe. W zakończeniu z kolei spróbuję pokazać istniejące luki i te obszary badawcze, które zasługują na eksplorację, kiedy mówimy o narracji w zmieniającym się filmie, który coraz częściej staje się integralną częścią bardzo różnorodnego pejzażu audiowizualnego.

nie do kognitywnej teorii filmu, Wydawnictwo Uniwersytetu Jagiellońskiego, Kraków 1999; idem, Rozumienie opowiadania filmowego, Wydawnictwo Uniwersytetu Jagiellońskiego, Kraków 1999; J. Ostaszewski (red.), Kognitywna teoria filmu. Antologia przekładów, Baran i Suszczyński, Kraków 1999). 


\section{Nowe oblicze narratologii}

W latach 90. - jak zauważa Magdalena Rembowska-Płuciennik - doszło do wyodrębnienia narratologii kognitywistycznej jako subdyscypliny, co zresztą związane jest z dokonaniem się zwrotu w obrębie narratologii jako takiej i przejściem od klasycznych teorii narracji do postklasycznych. Ów przełom związany jest $\mathrm{z}$ jednej strony $\mathrm{z}$ rozszerzeniem zasięgu dyscyplin, w ramach których o narracji się mówi, ale także wykorzystaniem zróżnicowanych metodologii i perspektyw w ,zremasterowanej” teorii narracji. Ta nie tyle ,ucieka” $\mathrm{z}$ getta formalizmu, strukturalizmu i gramatyki generatywnej - dziedzin, które do tej pory determinowały badania narratologiczne - ile otwiera dotychczas pilnie strzeżone granice dyscypliny. Powstaje więc narratologia postklasyczna - interdyscyplinarnie ukierunkowana, w ramach której „uzupełnia się badania strukturalistyczne o tematy i metody z założenia przez strukturalizm odrzucane (lub wcześniej po prostu nieznane), ale także eksploruje nowe możliwości dawnych modeli opisu dzieła literackiego, łącząc je ze studiami genderowymi, kulturowymi, postkolonialnymi, kognitywizmem, socjolingwistyką, psychologią"7. Badaczy nie przestają co prawda interesować relacje zachodzące pomiędzy elementami o czysto formalnym charakterze (a więc w filmoznawstwie najczęściej sekwencyjność zdarzeń w ich przyczynowo-skutkowym

M. Rembowska-Płuciennik, Poetyka intersubiektywności. Kognitywistyczna teoria narracji a proza XX wieku, Fundacja na rzecz Nauki Polskiej, Toruń 2012, s. 70. bądź motywowanym w inny sposób teleologicznym przebiegiem historii), lecz wskazują na konieczność uchwycenia ich w korelacji z aktywnością podmiotów, które są nadawcami i odbiorcami (czytelnikami, widzami) tekstów narracyjnych. Ponieważ narracja jest ludzką opowieścią o ludzkich podmiotach służącą zrozumieniu przez nie świata i umożliwiającą niejednokrotnie ukonstytuowanie się tożsamości jednostki, konieczne wydaje się uwzględnienie roli procesów poznawczych w procesie jej opisu ${ }^{8}$. W filmoznawstwie kognitywistycznie ukierunkowaną narratologię reprezentują między innymi tacy badacze, jak: David Bordwell, Kristin Thomson czy Edward Branigan, Noël Carroll, Gregory Currie 9 , i to właśnie z ich dorobku oraz ustaleń (może poza słabiej znanym Currie'em) korzystają od lat dziewięćdziesiątych polscy uczeni, przywiązani do neoformalizmu jako metody analitycznej wykorzystywanej ${ }^{10}$

Zob. np. J. Trzebiński, Narracja jako sposób rozumienia świata, w: B. Owczarek, Z. Mitosek, W. Grajewski (red.), Praktyki opowiadania, Universitas, Kraków 2001, s. 87-120; K. Rosner, Narracja jako struktura rozumienia, „Teksty Drugie” 1999, nr 3.

9 Zob. D. Bordwell, Narration in the Fiction Film (1985) czy Making Meaning: Inference and Rhetoric in the Interpretation of Cinema (1989); K. Thomson, Breaking Glass Armor: Neoformalist Film Analysis (1988); E. Branigan, Narrative Comprehension and Film (1992); N. Carroll, Mystifying Movies: Fads and Fallacies in Contemporary Film Theory (1988); G. Currie, Image and Mind: Film, Philosophy and Cognitive Science (1995).

10 Andrzej Zalewski, pisząc „Otóż sugeruję, że ta kognitywna samoświadomość przedstawicieli kognitywizmu jest dość zwodnicza i że implikacje ich poczynań wiodą w stronę tradycyj- 
przez kognitywistów oraz ceniący jej zdroworozsądkowe podejście i przywiązanie do myślenia potocznego. Mniejszy oddźwięk wśród narratologów znalazły te kognitywistyczne koncepcje, które wracają do psychoanalitycznych korzeni, a więc rzadziej badacze odwołują się do ustaleń Petera Wussa czy Petera Ohlera ${ }^{11}$. Niepodważalna wydaje się za to nierozłączność kognitywizmu jako teorii i neoformalizmu jako metody analitycznej, co pokazuje dobrze, że postklasyczne teorie narracji nie rezygnują $\mathrm{z}$ dziedzictwa strukturalistyczno-formalnego, ale jedynie poddają je transformacji. Trzecim ważnym ogniwem i kierunkiem, w którym podąża uwaga badaczy z Wisconsin, a w ślad za nimi refleksja badaczy z Polski, jest historia, dokładniej: historyczna zmienność stylu czy poetyki. David Bordwell wprowadza termin modes of film practice, czyli tryby praktyki filmo-

nej filozoficznej epistemologii, ucieleśnionej na przykład w dwudziestowiecznej fenomenologii. Fenomenologia świata codziennego (lub też, inaczej to nazywając, «naturalnego nastawienia») jest modelem, w którym spełnia się przedsięwzięta przez omawianych tu badaczy konstrukcja teorii filmowej. Czy jest to model jedynie możliwy tego nie chciałbym przesądzać”, kwestionuje jednorodność nurtu, jakim jest kognitywizm, i wskazuje na jego pokrewieństwa z fenomenologią. A. Zalewski, Zapoznane dziedzictwo: czy kognitywna teoria filmu jest kognitywna?, „Principia” 2000, t. XXVI, s. 16-42.

11 Chodzi o takie pozycje jak: P. Wuss, Cinematic Narration and Its Psychological Impact: Functions of Cognition, Emotion and Play, Cambridge Scholar Publishing, Newcastle upon Tyne 2009; P. Ohler, Kognitive Filmpsychologie: Verarbeitung und mentale Repräsentation narrativer Filme, Maks Publikationen Münster, Münster 1994. wej, na które składają się: forma przedstawienia filmowego, ale także sposób przemysłowo-filmowej produkcji (mode of production). Styl jest więc zmienny, bo jest technologicznie i ideologicznie uwarunkowany, co należy brać pod uwagę.

Ponadto subdyscypliną narratologii inspirowaną kognitywizmem (choć nie tylko, bo także semiotyką, językoznawstwem, literaturoznawstwem czy medioznawstwem) jest także narratologia transmedialna, głosząca, że narracja „może być równie dobrze przedstawiona w wielu mediach: w medium językowym, obrazowym, a nawet przestrzennym"12. Jej ukonstytuowanie się związane jest z narodzinami mediów cyfrowych oraz przeobrażeniami krajobrazu medialnego, który staje się coraz bardziej urozmaicony i zróżnicowany. Do zasadniczych założeń narratologii transmedialnej ${ }^{13}$, z której dorobku korzystają przede wszystkim medioznawcy, ale też literaturoznawcy ${ }^{14}$, należy zaś przekonanie, że narracja nie ma jedynie charakteru językowego, medium

12 K. Kaczmarczyk, Opodstawowych założeniach narratologii transmedialnej $i$ o jej miejscu wśród narratologii klasycznych i postklasycznych, w: K. Kaczmarczyk (red.), Narratologia transmedialna. Teorie, praktyki, wyzwania, Universitas, Kraków 2018.

13 Jej przedstawicielami są Henry Jenkins, Marie-Laure Ryan, David Herman, Linda Hutcheon, Jan-Noël Thon, Lisbeth Klastrup, Claus Toft-Nielsen.

14 Zob. K.M. Maj, Allotopie. Topografie światów fikcyjnych, Universitas, Kraków 2015; idem, Stowo gra znaczy świat. Przestrzeń gry wideo w kognitywnej teorii narracji, „Teksty Drugie” 2017, nr 3; P. Kubiński, Gry wideo w świetle narratologii transmedialnej oraz koncepcji światoopowieści (storyworld), „Tekstualia” 2015, nr 4(43). 
zaś stanowi w tym wypadku kanał komunikacji (bądź techniczny nośnik tejże). Różne media charakteryzują się różnymi możliwościami i zakresem reprezentacji narracji, są one pod tym względem gradowalne, rozmaite kategorie narracyjne mogę być od medium niezależne lub dla konkretnego medium specyficzne. Przede wszystkim jednak w centrum zainteresowania narratologii transmedialnej stoi nie tyle fabuła, ile świat; w rezultacie nie chodzi o zaangażowanie w opowiadaną historię i jej przebieg poprzez proces projekcji-identyfikacji, lecz o doświadczenie immersji w świecie - często materialne oraz cielesne. Tekst nie jest już spójną, zamkniętą całością, ale jedynie konstruktem, planem, szkieletem, który wymaga/ domaga się wypełnienia i zaprasza odbiorcę do podjęcia procedury aktywizacji (teksty jako blueprints for simulation). Takimi tekstami są, w największym stopniu, gry komputerowe, ale przecież także filmy interaktywne. Choć zasadniczo kino opowiada o wydarzeniach, które już się dokonały, to jednak współcześnie coraz częściej powstają także dzieła skłaniające odbiorcę „do działań, które można uznać za narracyjne lub które skutkują zmianami w świecie narracji"15. O światocentryczności kina świadczy nurt filmów superbohaterskich; o tym, że nie stawia ono już jedynie na domknięte teksty film Czarne lustro: Bandersnatch (2018). Tymczasem w filmoznawczych badaniach perspektywa transmedialna jest słabo obecna i stanowi lukę, która domaga się wypełnienia.

15 K. Kaczmarczyk, op. cit., s. 57.

\section{Oblicza polskiej narratologii}

Powstałe w ostatnich dwóch dekadach w Polsce książki narratologiczne można podzielić na różne sposoby. Obok tych, które wyrastają z kognitywistycznej teorii filmu, znajdziemy także pozycje odnoszące się i bezpośrednio czerpiące z tradycji teorii literatury, korzystające z dorobku i ustaleń tej dyscypliny poprzez ich aplikowanie do badań filmoznawczych z wprowadzeniem niezbędnych zastrzeżeń i modyfikacji (Birkholc), co czynili też na przykład Bordwell i Branigan, anektując pojęcie fokalizacji z koncepcji Gérarda Genette'a, przepracowanej potem przez Mieke Bal. Można przyjąć też inne kryterium i w odmienny sposób podzielić dokonania rodzimej narratologii. Przede wszystkim wyróżnić należy propozycje autorskie starające się przedstawić oryginale koncepcje typologizacji narracji w ich diachronicznym lub synchronicznym ujęciu (Kłys, Ostaszewski) - są to w pewnym zakresie książki stanowiące odpowiedź na najbardziej wpływową publikację Bordwella Narration in Fiction Films ${ }^{16}$. Kolejną grupę tworzą teksty (książki i artykuły) skupiające się wokół konkretnych narracyjnych zabiegów i chwytów (takich jak ramy modalne) czy szerszych kategorii narracyjnych (takich jak subiektywizacja, przestrzeń, czas). Wreszcie znaczący wkład w rozwój polskiej narratologii filmowej mają pozycje podejmujące się opisania konkretnej poetyki historycznej

16 Jej fragment w tłumaczeniu Tomasza Kłysa ukazał się w „Kwartalniku Filmowym”. Zob. D. Bordwell, Narracja parametryczna, „Kwartalnik Filmowy" 2010, nr 71-72. 
czy stylu, ale czyniące narrację kategorią kluczową do zrozumienia przemian zachodzących we współczesnym kinie (Zalewski, Syska, Szczekała). Z zakresu moich zainteresowań musiałam wyłączyć teksty analityczne, niejednokrotnie niezwykle ciekawe i wartościowe, lecz zogniskowane wokół jednego najczęściej filmu lub twórcy i pokazujące użycie kategorii analitycznych raczej, niż wprowadzające istotne teoretyczno- czy historyczno-narratologiczne ustalenia.

\section{W kręgu kognitywistycznych inspiracji}

Do pierwszej ze wskazanych grup należą: dziś już nieco zapomniana i chyba nigdy w wystarczającym stopniu niedoceniona książka Tomasza Kłysa Film fikcji i jego dominanty oraz najnowsza publikacja Jacka Ostaszewskiego, porządkująca i systematyzująca pole badawcze Historia narracji filmowej.

Kłys jako pierwszy badacz przybliża kognitywistyczną teorię narracji na gruncie polskiego filmoznawstwa, jednocześnie z niej korzysta i konfrontuje ją z innymi koncepcjami. W jego pracy $\mathrm{z}$ jednej strony kluczowe jest przepracowanie i dopracowanie pojęcia diegezy, z drugiej zaś autor skupia się na tym, co dla kognitywistów kluczowe, czyli procedurze budowania znaczeń, a więc na procesach poznawczych. Sercem jego koncepcji jest jednak przekonanie o istnieniu w dziełach filmowych wyrazistych dominant diegetycznych (takich jak fabuła, efekt diegetyczny, dyskurs, spektakl, intencja zwrotna), determinujących charakter tekstu i intencjonalnie weń wpisanych, przy zaznaczonej możliwości równoczesnego istnienia wszystkich, choć tylko jednej pozycjonowanej jako wiodąca:

[...] w zasadzie w każdym filmie fikcji na poziomie diegetycznych referentów coś się dzieje w tak czy inaczej ,jakoś” istniejącym świecie, a więc jest i fabuła, i efekt diegetyczny, jako niezbywalne komponenty fikcji, w minimalnym przynajmniej stopniu zawsze obecne. Z racji statusu diegesis jako przedmiotu intencjonalnego zawsze można domniemywać wyrażoną przezeń - choćby i nie w jawny, a jedynie implikowany i nieuświadomiony sposób - argumentację (dyskursywny wywód). Jest też każdy film „dla widza”, a jako taki - jest spektaklem. A „zwrotny”, bo nieuchronnie implikujący nadawcze wybory, jest $\mathrm{w}$ swej totalności cały tekstualny system wyboru środków, od nieubłaganie obecnej ramy kadru do jakościowego uposażenia jakiegokolwiek diegetycznego referentu. Rzeczy konieczne a priori należy jednak odróżniać od intencjonalnych dominant, które są nakierowaniem intencji właśnie na którąś z tych apriorycznych konieczności ${ }^{17}$.

Koncepcja związanego z łódzkim ośrodkiem badacza $\mathrm{z}$ punktu widzenia współczesnego kina wymaga zapewne przepracowania i uzupełnienia. Nie jest ona także pełna i wyczerpująca, nie uwzględnia bowiem narracji interaktywnej czy dzieł spod znaku puzzle films, których dominantą jest procesualność czy performatywność. Wątpliwości budzić może na przykład wyróżnienie intencji zwrotnej jako dominanty, gdyż filmy Georges'a Mélièsa są wyraźnie „zwrotne”, ale czy intencjonalnie? Jednocześnie bez wątpienia jest to kino z dominantą spektaklu (skądinąd jak

${ }^{17}$ T. Kłys, Film fikcji..., op. cit., s. 64. 
najbardziej intencjonalnego), ale czy obecność spektaklu nie jest sine qua non związana ze zwrotnością intencji? Bez względu jednak na luki, które posiada książka Kłysa - wynikające w większości przypadków z faktu, że od jej publikacji minęło prawie dwadzieścia lat, co dla kina jest całą epoką - posiada ona walor koncepcji pionierskiej, jednocześnie wciąż aktualnej i doskonale wyczuwającej w wielu wypadkach kierunki rozwoju kina.

Historia narracji filmowej Jacka Ostaszewskiego jest pozycją holistyczną w swym założeniu. Choć w tym wypadku dominuje perspektywa diachroniczna, nie oznacza to, że jej autor nie stara się wydobyć i wskazać na pewną ,uniwersalność" wyróżnionych przez siebie modeli narracji filmowej, dominujących i krystalizujących się w konkretnych momentach rozwoju kina, ale nadal niejako ,aktualizowanych” w filmowej praktyce. Co jednak najważniejsze, propozycja Ostaszewskiego jest z jednej strony komplementarna względem klasycznej już Bordwellowskiej koncepcji przedstawionej w Narration in the Fiction Films, $\mathrm{z}$ drugiej zaś wchodzi z nią w polemikę. Wskazane kolejno ,tryby narracyjne” (jako powiedziałby Bordwell) - narracja wczesnego kina, narracja melodramatyczna, narracja klasyczna i kino hollywoodzkie, narracje kina postmodernistycznego - znajdą swoje odpowiedniki, choć nie w skali jeden do jednego, w postaci narracji klasycznej, parametrycznej, kina artystycznego oraz materialistyczno-historycznej. Ten ostatni rodzaj narracji jest stosunkowo najsłabiej obecny w dyskursie Ostaszewskiego.
Gdyby nałożyć na przedstawione propozycje rozwiązania zaproponowane przez Tomasza Kłysa, uzyskalibyśmy niemal pełen przegląd możliwości narracyjnych filmu fikcji i ciekawą siatkę wzajemnych zależności pomiędzy historycznymi modelami opowiadania (Ostaszewski), trybami narracji (Bordwell) oraz dominantami narracyjnymi (Kłys). Wszyscy wymienieni badacze zgodni są właściwie co do centralnej i kluczowej roli kina klasycznego, operującego narracją klasyczną i posługującego się dominantą fabuły. Jednak już w wypadku narracji kina artystycznego sprawy się komplikują, bo w ujęciu Ostaszewskiego ten tryb opowiadania wykorzystuje zarówno kino modernistyczne, jak i postmodernistyczne. Ponadto na przykład tryb narracji materialistyczno-historycznej powiązać należy w największej mierze z dominantą dyskursu, ale też bez wątpienia są to filmy samozwrotne. Zaletą Historii narracji filmowej jest bez wątpienia decyzja podjęta przez autora o niewyznaczaniu granic oraz radykalizowaniu sądów, co często jest grzechem naczelnym wszelkich projektów typologizujących. Ostaszewski wskazuje na przykład, że wczesne kino zgodnie z ogólnie panującym przekonaniem było ,kinem atrakcji” (dominanta spektaklu), ale tendencja do ,narratywizacji” przekazu także jest w nim obecna, zwłaszcza w tzw. filmach pogoni (chase films), mamy więc w gruncie rzeczy do czynienia z ,opowiadaniem z udziałem atrakcji"18. Jak czytamy we wstępie:

${ }^{18}$ J. Ostaszewski, Historia narracji.., op. cit., s. 43. 
Filmy te niejako mimochodem, pokazując „dzianie się”, zaczynały przedstawiać akcję. Ale nawet gdy już zaczęto opowiadać historie, to historie te nie miały jeszcze charakteru zamkniętych opowiadań. Ze względu na nieistotność w tym okresie podziału na dokument i fabułę, ekshibicjonistyczną otwartość widowiska - bez wyraźnie zamkniętej diegezy, czyli świata przedstawionego, przy nieobecności w filmie ,organizatora obrazu" jako czynnika sprawczego można by ten pierwszy etap w historii kina nazwać fazą quasi-fabularną ${ }^{19}$.

Oryginalne jest też w koncepcji Ostaszewskiego wyodrębnienie narracji melodramatycznej jako ogniwa łączącego kino wczesne z kinem klasycznym. O ile u Bordwella mamy do czynienia z gwałtownym przeskokiem, o tyle Ostaszewski optuje za ewolucją i sprawnie jej istnienie dowodzi, co sprawia, że wypełnia istniejące luki i łagodzi ekstremizm.

\section{Narracja filmowa w uszczegółowieniu}

Wiele artykułów i książek filmoznawczych opublikowanych przez rodzimych badaczy podejmuje także zagadnienia związane z konkretnymi rozwiązaniami narracyjnymi. Co jednak zaskakujące, w niewielkim stopniu przez polskich badaczy rozważane są powiązania pomiędzy narracją a kluczowymi kategoriami strukturalnymi świata przedstawionego, które ta modeluje, a więc na przykład czasem, przestrzenią czy opowiadaniem (które rozumiem tu jako sposób rozpro-

19 Ibidem, s. 9. wadzenia wydarzeń fabularnych po sjużecie i łączę z pojęciem dramaturgii) ${ }^{20}$. $\mathrm{Na}$ gruncie polskim opracowania doczekała się przede wszystkim kategoria przestrzeni filmowej, za sprawą, czerpiącej także z dorobku szkoły z Wisconsin, książki Elżbiety Ostrowskiej Przestrzeń filmowa. Autorka wyróżnia dwa rodzaje przestrzeni: znarratywizowaną oraz nieznarratywizowaną. Ten drugi rodzaj dotyczy sytuacji, w których konstrukcje przestrzenne zachowują swoistą autonomię względem struktur fabularnych, co miało miejsce już we wczesnym kinie, ale stanowiło także cechę charakterystyczną klasycznych musicali Busby'ego Berkeleya czy dzieł sowieckiej szkoły montażowej. Przestrzeń znarratywizowana z kolei podporządkowana jest prymatowi opowiadanej historii i jej pojawienie się wiąże się z narodzinami kina narracyjnej integralności, przedkładającego opowiadanie nad pokazywanie. Uznając kategorię przestrzeni za prymarną dla filmowego opowiadania (nie ma dzieła filmowego bez filmowej przestrzeni), Ostrowska konkluduje, że przestrzeń: ,jest całkowicie «zrepresjonowana» przez dyskurs przezeń konstruowany. [...] jest ona konstruowana [...] wedle reguł narzucanych przez rodzaj dyskursu, aktualizowanego poprzez określony model narracji [...] czy też schemat gatunkowy $[\ldots]^{\prime 21}$. Jednocześnie badaczka zastrzega, że istnieją też takie nurty i do-

20 Kognitywiści wskazują na czas, przestrzeń i logikę jako trzy podstawowe podsystemy formalne opowiadania, przy czym logika opowiadania związana jest przede wszystkim z kategorią przyczynowości.

21 E. Ostrowska, Przestrzeń filmowa, Rabid, Kraków 2000, s. 2015-2016. 
konania w obrębie filmu, które ,kwestionują bądź naruszają, w mniejszym lub większym stopniu, regułę podporządkowania przestrzeni innym elementom struktury przedstawieniowej, które ulega radykalnej transformacji. Dopiero tutaj staje się ona autonomicznym obiektem eksploracji, penetrowanym częstokroć niezależnie od zaludniających ją obiektów i zachodzących w niej zdarzeń" 22 . Nawet jednak to zastrzeżenie sprawia, że wprowadzony podział daje się utrzymać.

Książka Ostrowskiej stała się inspiracją i punktem wyjścia moich rozważań zawartych w książce Strategie labiryntowe $w$ filmie fikcji $i^{23}$, w której korzystając z poczynionych przez nią ustaleń, staram się pokazać, jak specyficzna forma przestrzenna, jaką jest labirynt, może determinować różne poziomy dzieła filmowego. Mamy więc do czynienia z filmowymi labiryntami przedstawionymi i przedstawiającymi. Przestrzeń przedstawiona, gdy jest labiryntowa, pozostaje znarratywizowana, podporządkowana dyktatowi fabuły, choć nie w restrykcyjny sposób. W tym wypadku może dojść do jej częściowej autonomizacji, ponieważ zasady organizowania miejsc w przestrzeń zostają rozluźnione, a proces konstruowania znaczeń podporządkowany jest już nie tylko fabule, ale także specyfice przestrzeni, która to swoim charakterem narzuci nam sposób odczytania tekstu, wpływa na jego wymowę i interpretację. Z kolei strategia labiryntów przedstawiających zakłada narzucenie przez labirynt jako strukturę

$22 \quad$ Ibidem, s. 2017.

23 K. Żyto, Strategie labiryntowe $w$ filmie fikcji, Wydawnictwo Uniwersytetu Łódzkiego, Łódź 2010. przestrzenną swoich cech charakterystycznych wszystkim elementom formalnym opowiadania, przede wszystkim czasowi i logice opowiadania, w wyniku czego o przestrzeniach labiryntowych nie tylko się opowiada, ale i opowiada się nimi. W tym wypadku przestrzeń nie jest znarratywizowana, a labiryntowa staje cała struktura narracyjna. Koncepcja labiryntowej narracji w późniejszych badaniach zostaje zestawiona $\mathrm{z}$ koncepcją narracji-kłącza, zaproponowaną przez Małgorzatę Jakubowską. Narracja-labirynt i narracja-kłącze mają wiele elementów wspólnych, ale także takich, które je różnią. Oba modele konstruowania filmowej wypowiedzi rezygnują z klasycznych reguł opowiadania, przez co wpływają na poziom artykulacji czasoprzestrzennych, ale i logikę opowiadania. Przy czym z kategorią kłącza należy się posłużyć, ,jeśli chcemy podkreślić «nieobecność apriorycznego ładu» oraz sprzeczne hipotezy generowane przez te narracje, szczególnie co do ontologicznego i epistemologicznego statusu opisywanego świata"24 Narracje labiryntowe związane są zaś z porządkiem rozumu, nawet jeśli ten jest paradoksalny. Labirynt wyraża tęsknotę za porządkiem i celowością, których się poszukuje, pokonując jego korytarze (także te narracyjne). W wypadku narracji-labiryntu i narracji-kłącza dominantą przekształceń jest czas.

${ }^{24}$ M. Jakubowska, K. Żyto, Labirynt i kłacze paradygmaty wspótczesnej narracji filmowej, w: R.W. Kluszczyński, T. Kłys, N. Korczarowska-Różycka (red.), Paradygmaty wspótczesnego kina, Wydawnictwo Uniwersytetu Łódzkiego, Łódź 2015, s. 20. 
Problematyce czasu w polskim filmoznawstwie poświęcono niewiele miejsca. Alicja Helman już w 1970 roku proponuje stosowanie kategorii czasoprzestrzeni. Zdaniem badaczki w filmie nie dominuje ani czasowość, ani przestrzenność - są to elementy formalnie nierozdzielne, możliwe do opisania za pomocą czynności zastępczych, można więc mówić na przykład o uprzestrzennieniu przebiegów czasowych ${ }^{25}$. Problematyka czasu jako elementu konstrukcji narracyjnej podejmowana była przez Andrzeja Zalewskiego w artykule Meandry czasu teraźniejszego oraz Barbarę Szczekałę w tekście zatytułowanym Czas niszczy wszystko. Fenomen odwróconej chronologii $w$ opowiadaniu filmowym. W obu wypadkach mamy jednak do czynienia nie tyle z szerzej zakrojonymi koncepcjami, ile z próbą opisu wybranych aspektów czasowości ${ }^{26}$. Kategoria czasu stosunkowo najszerzej wybrzmiewa w monograficznej książce Małgorzaty Jakubowskiej poświęconej twórczości Wojciecha Jerzego $\mathrm{Hasa}^{27}$, ale jest to z całą pewnością zagadnienie wciąż domagające się kompleksowego i szczegółowego opracowania.

Wiele interesujących tekstów polscy filmoznawcy zajmujący się narratolo-

25 A. Helman, $O$ dziele filmowym: materiat, technika, budowa, Wydawnictwo Literackie, Kraków 1970.

26 Zob. A. Zalewski, Meandry czasu teraźniejszego, „Kwartalnik Filmowy” 2001, nr 34; B. Szczekała, Czas niszczy wszystko. Fenomen odwróconej chronologii w opowiadaniu filmowym, „Kwartalnik Filmowy” 2014, nr 86.

27 M. Jakubowska, Kryształy czasu. Kino Wojciecha Jerzego Hasa, Wydawnictwo Uniwersytetu Łódzkiego - Wydawnictwo PWSFTviT, Łódź 2013. gią poświęcili konkretnym zabiegom i chwytom wykorzystywanym w procesie opowiadania. Podstawową inspiracją w tym wypadku były najczęściej ustalenia literaturoznawców, a zasadniczym celem, jakie konkretne propozycje badawcze przed sobą stawiały - weryfikacja przydatności i użyteczności kategorii teoretycznoliterackich w filmoznawczej praktyce analitycznej. Często oczywiście koncepcje te prowadziły do wskazywania na film jako na medium narracyjnie odrębne, autonomiczne i posiadające swoją specyfikę oraz były argumentem w nieustającej dyskusji na temat jego „niepodległości” także i w tym względzie. Narracyjność jest jednak elementem, który w największym stopniu łączy literaturę i film, co zauważa na przykład Brian McFarlane ${ }^{28}$, a jednocześnie walka między filmem a literaturą o prymat wśród sztuk narracyjnych wydaje się toczyć w najlepsze.

Olbrzymi wkład w rozwój rodzimej narratologii w tym zakresie ma oczywiście Mirosław Przylipiak, jego - niestety nieopublikowany - doktorat Modele podmiotowości filmowej jest ważną pracą w tym zakresie. To, do czego dziś może dotrzeć czytelnik, to jedynie rozproszone, aczkolwiek inspirujące i cechujące się niezwykłą precyzją terminologiczną, teksty. W artykule Narrator literacki, narrator filmowy Przylipiak, wychodząc od ustaleń strukturalisty Sey-

28 B. McFarlane, Tto, problemy i nowe propozycje badawcze, „Kwartalnik Filmowy” 1999, nr 26-27 (fragment książki Novel to Film: An Introduction to the Theory of Adaptation, Clarendon Press, Oxford 1996). 
moura Chatmana ${ }^{29}$, podkreśla, że drogi literatury i filmu dawno się rozeszły, pokrewieństwo między nimi istnieje na poziomie raczej autora implikowanego (bezgłośnej instancji posiadającej moc szeregowania i rozprowadzania zdarzeń) niż narratora, ten bowiem w filmie nie istnieje w takim znaczeniu, w jakim rozumie się go w literaturoznawstwie. Przylipiak pisze więc o kategorii ,filmowego nadawcy wewnątrztekstowego", którego specyfiki „należy szukać na obszarach związków między nim a wizualnym i akustycznym ukształtowaniem czasu i przestrzeni w kinie"30. We wcześniejszym tekście z 1985 roku optuje jeszcze za postaciami będącymi „dysponentami narracji filmowej" i podkreśla, że w tekście literackim są one zespolone, ale w filmie ulegają rozbiciu na: narratora formalnego (gdy istnieje dystans czasowy między momentem opowiadania i akcji, na przykład w retrospekcjach), obserwatora (odpowiednik narratora auktorialnego), narratora uczestnika (selekcji zdarzeń dokonuje się ze względu na uczestnictwo w nich bohatera) oraz kreatora (,dysponent kształtu filmowego świata przedstawionego" ${ }^{31}$ ). Rozważania nad kategorią filmowego „narratora” prowadzą go w kierunku zagadnienia subiektywizacji.

W 1992 roku Przylipiak dokonuje przeglądu, głównie anglosaskich i pol-

29 Chodzi o książkę: S. Chatman, Story and Discourse: Narrative Structures in Fiction and Film, Cornell University Press, Ithaca 1978.

30 M. Przylipiak, Narrator literacki, ,narrator," filmowy, „Studia Filmoznawcze” 1990, t. IX, s. 81.

31 M. Przylipiak, O kategorii narratora $w$ filmie, „Powiększenie” 1985, nr 1(17), s. 30. skich, propozycji badawczych podejmujących ten problem, posługując się konsekwentnie terminem nadawcy wewnątrztekstowego. Przywołuje w sposób krytyczne ustalenia Edwarda Branigana $^{32}$, Bruce'a F. Kawina ${ }^{33}$, ale też Eugeniusza Białego czy Stanisława Brejdyganta $^{34}$ i konkluduje, że wiele propozycji jest niekonsekwentnych i zachodzi na siebie, gdyż problematyka jest skomplikowana i niejednoznaczna. Według Przylipiaka ,potrafimy coraz lepiej opisywać techniki subiektywizacji”, jednak ,[n]adawca wewnątrztekstowy pozostaje kategorią nierozpoznaną"35.

Jeden ze szczególnych rodzajów nadawcy wewnątrztekstowego opisuje Jacek Ostaszewski, charakteryzując narratora niewiarygodnego. W tym wypadku kategoria narracyjna ma swoje korzenie literackie (Wayne C. Booth, Rhetoric of Fiction, 1961), a autor tekstu stara się wskazać jej filmowe „warianty” - w rezultacie pisze nie tylko o ,narratorze" niewiarygodnym, ale także o niewiarygodnym fokalizatorze, który ,zamiast być gwarantem wiedzy o świecie przed-

32 Kluczowa jest tu pozycja: E. Branigan, Point of View in Cinema: A Theory of Narration nad Subjectivity in Classical Film, Mouton Publishers, Berlin-New York-Amsterdam 1984.

33 B.F. Kawin, Mindscreen: Bergman, Godard and First Person Narration, Princeton University Press, Princeton 1978.

34 E. Biały, Narracja a rama modalna dzieła filmowego - uwagi analityczne, w: M. Hendrykowski (red.), Z zagadnień stylu i kompozycji w filmie współczesnym, Wydawnictwo Naukowe UAM, Poznań 1982; S. Brejdygant, Narracja subiektywna, „Kino” 1969, nr 3.

35 M. Przylipiak, O kategorii nadawcy wewnatrztekstowego dzieła filmowego, w: A. Helman (red.), Autor, film, odbiorca, Wiedza o Kulturze, Wrocław 1991, s. 80. 
stawionym i prawdy w jego ramach, może nie zdawać sobie sprawy ze swojego położenia i z upośledzenia swoich władz poznawczych, może mylić się w ocenie sytuacji, może wreszcie zmyślać, ubarwiając zdarzenia, lub - po prostu - może kłamać"36. Instancja narracji niewiarygodnej dominuje w filmach z zabiegami subiektywizującymi i na ogół ma charakter podmiotowy. Ostaszewski zauważa, że niewiarygodna może być co prawda także narracja obiektywna, ale temu wariantowi niewiarygodności poświęca stosunkowo niewiele uwagi.

Wyraźnie więc to przede wszystkim subiektywizacja jest elementem zainteresowania badaczy, co wynika z rosnącego znaczenia podmiotu oraz tożsamości, jak i perypetii tych kategorii we współczesnym świecie, o czym szerzej piszą filozofowie i teoretycy kultury. Świadczą o tym także dwie kolejne publikacje: nastawiony na typologizację i porządkujący pole badawcze, $\mathrm{z}$ dzisiejszej perspektywy wymagający przepracowania, artykuł Przylipiaka $O$ subiektywizacji narracji filmowej z 1987 roku oraz napisany trzy dekady później przez Ostaszewskiego tekst Techniki subiektywizacji $w$ filmie fabularnym. Ten drugi na nowo naświetla problematykę subiektywizacji, w dużej mierze w ujęciu historycznym, ponadto przedstawia definicyjne kłopoty i wątpliwości z nią związane, a jednocześnie skupia się na kinie współczesnym, jego sposobach subiektywizowania narracji, z których część stała się pokłosiem konwergencji mediów i wpływu na przykład

36 J. Ostaszewski, Narrator niewiarygodny w filmie fabularnym, „Kwartalnik Filmowy” 2010, nr 71-72, s. 61. rozwiązań charakterystycznych dla gier komputerowych na film fikcji ${ }^{37}$.

Symptomatyczne, tak czy inaczej, pozostaje stwierdzenie Przylipiaka: „Sądzę, że subiektywizacje filmowe mają swą bardzo silną, uwarunkowaną tworzywowo specyfikę"38. Jest ono świadectwem nieustającej potrzeby sfinalizowania rozwodu filmu i literatury, który mimo dążeń ze strony niewiernego małżonka-filmu nadal nie nastąpił. Bez wątpienia nie na gruncie subiektywizacji, czego najlepszym dowodem jest najnowsza publikacja autorstwa Roberta Birkholca, pracownika Instytutu Literatury Polskiej (!) w Zakładzie Komparatystyki Uniwersytetu Wrocławskiego. Podwójna perspektywa. O subiektywizacji zapośredniczonej $w$ filmie to dowód uwikłania narratologii filmowej w dyskurs literacki, ale nie jest to bynajmniej zarzut, autor bowiem sprawnie pokazuje, że badania takie mogą wciąż przynosić ciekawe rezultaty. Birkholc konstruuje swój wywód w sposób klasyczny. Pierwsza część ma charakter teoretyczny, druga - analityczny; obie wydają się niezbędne. Najpierw zostaje uporządkowany stan badań, potem zaś niczym wisienka na torcie pojawia się seria oryginalnych i ciekawych, filmoznawczo zaś ,rasowych”, analiz, z którymi bez względu na to, czy są dla nas przekonujące czy nie, warto się zapoznać, bo jest to lektura inspirująca, ale i skłaniająca do polemiki.

37 M. Przylipiak, O subiektywizacji narracji filmowej, „Studia Filmoznawcze” 1987, t. VII (red. J. Trzynadlowski); J. Ostaszewski, Techniki subiektywizacji w filmie fabularnym, „Kwartalnik Filmowy” 2017, nr 97-98.

38 M. Przylipiak, O subiektywizacji..., op. cit., s. 239. 
W dalszej części artykułu skupię się na przedstawionej przez wrocławskiego badacza propozycji teoretycznej i jej użyteczności. Po przedstawieniu koncepcji literackich dotyczących mowy pozornie zależnej, historycznego i teoretycznego zarysu rozwoju subiektywizacji w filmie ze szczególnym uwzględnieniem kategorii fokalizacji (wobec których Birkholc zachowuje dystans i z którymi polemizuje) czytelnikowi przedstawiona zostaje jego autorska koncepcja. Birkholc kładzie nacisk na nakładanie się (interferencję) podmiotów narracyjnych, a więc tego, co subiektywne oraz obiektywne. Warto pamiętać, że gdy mamy do czynienia z kategorią podmiotu, to $\mathrm{w}$ gruncie rzeczy zawsze mówimy o subiektywizacji, tyle że jest ona zogniskowana przez odrębne instancje narracyjne o różnym poziomie dystansu i zaangażowania w przedstawiane wydarzenia. Dlatego autor Podwójnej perspektywy pisze o ,współobecności perspektywy bohatera i perspektywy wobec niej zewnętrznej"'39. Jego zasadniczym celem jest zaś pokazanie, jak tryb narracyjny w literaturze nazywany ,mową pozornie zależną" realizuje się w materii filmowej, gdzie przyjmuje kształt subiektywizacji zapośredniczonej.

Zastosowanie odpowiednich środków językowych w mowie pozornie zależnej takich jak nieprzeźroczysta składnia, charakterystyczne słownictwo czy ekspresyjne zwroty - wytwarza w czytelniku wrażenie, że narracja została „zabarwiona” emocjami lub sposobem myślenia postaci. Podobna sytuacja może występować w filmie. Zabiegi stylistyczne uzyskiwane na skutek

39 R. Birkholc, Podwójna perspektywa..., op. cit., S. 12 . modyfikacji obrazu lub dźwięku mogą być śladem podmiotowej perspektywy postaci. Funkcję tę mogą pełnić: nietypowe punkty widzenia kamery, szczególna kompozycja kadru, charakterystyczne oświetlenie, jaskrawa i nienaturalistyczna kolorystyka, asocjacyjny montaż czy modulacja dźwię$\mathrm{ku}^{40}$.

Subiektywizacja zapośredniczona oddaje myśli, uczucia, stany emocjonalne bohatera, ale nie w sposób bezpośredni. Nie dowiadujemy się, co dokładnie bohater poczuł czy pomyślał, gdyż „Narracja nie próbuje «reprodukować» odczuć i myśli bohatera, lecz tworzy rozmaite wariacje na temat jego postrzegania i odczuwania rzeczywistości. W rezultacie powstaje swojego rodzaju «dialog» między bohaterem wpisaną w tekst fokalizacją zewnętrzną a odbiorcą, który zachęcany jest do interpretacji określonych zabiegów formalnych" ${ }^{41}$.

Koncepcja subiektywizacji zapośredniczonej jest bez wątpienia przekonująca i klarowna. Pozwolę sobie w tym miejscu jedynie na dwie uwagi, z czego jedna ma charakter uzupełnienia. W książce brakuje odniesienia do omawianej przez Magdalenę Rembowską-Płuciennik koncepcji narracji intersubiektywnej. Badaczka podkreśla, że perspektywiczność jest cechą każdej ludzkiej kognicji, tę zaś warunkuje tryb działania naszej świadomości, która nieustająco ukierunkowana jest na intersubiektywność, czyli przetwarzanie i reprezentowanie cudzych stanów mentalnych. Tak więc każda narracja jest intersubiektywna, bo ,reprezentuje ludzką zdolność rozpoznawania/ podzielania/symulowania cudzej per-

\footnotetext{
40 Ibidem.

41 Ibidem, s. 121.
} 
spektywy, przyjmowania różnych punktów widzenia i wielostronnego (w sensie literalnym, jak i figuratywnym), imaginacyjnego przekraczania ograniczeń poznawczych"42.

Ponadto warto wyraźniej zaakcentować, co zresztą wybrzmiewa w teorii mowy pozornie zależnej, że subiektywizacja zapośredniczona implikuje nie tylko interferencyjność perspektyw, ale i to, że subiektywność bohatera poddawana jest refleksji, a fokalizacja zewnętrzna zdradza jakiś swój względem niej stosunek (na przykład ironię). Birkholc oczywiście o tym pisze, formułując następującą myśl: ,subiektywizacja zapośredniczona może wprowadzać swojego rodzaju dystans [czy jednak musi? - przyp. K.Ż.], np. poprzez wyolbrzymienie pewnych cech (nie)świadomości postaci”" ${ }^{43}$, ale to odbiorca ,musi dokonać interpretacji, zastanowić się nad znaczeniem środków zastosowanych w dziele oraz nad konstrukcją podmiotu filmowego"44. I tu właśnie film rozmija się z literaturą, w mowie pozornie zależnej językowe środki wyrazu zdradzają charakter stosunku narratora do postaw, myśli i uczuć postaci, filmowe środki stylistyczne nie są tak jednoznaczne i skodyfikowane. Powraca więc problem dyskutowany od lat, który roboczo nazwijmy problemem , języka filmu".

Z kwestią subiektywizacji związane są ramy narracyjne, czy - jak nazywa je Eugeniusz Biały - ,ramy modalne”. Zagadnienie to nie doczekało się szerszego opracowania, ale artykuły, które na ten

42 M. Rembowska-Płuciennik, op. cit., s. 124.

43 R. Birkholc, op. cit., s. 122.

44 Ibidem. temat powstały posiadają walor nowatorstwa. Biały pisze, że ,rama zakłada zawsze pewien świat, wobec którego świat przekazywany przez jakiś rodzaj narracji pozostaje w stosunku: przyległości (narracja obiektywna); tożsamości (apercepcyjna narracja subiektywna; lub opozycji (asocjacyjna narracja subiektywna)" ${ }^{45}$. Jego myśl rozwija Tomasz Kłys, który rozpatrując ramy jako chwyt poetyki negatywnej, wskazuje na kilka wariantów sytuacji, kiedy rama, zamiast znakować zmianę ontologii świata przedstawionego, wywołuje zachwianie albo zniweczenie uczucia jego „rzeczywistości”. Dzieje się tak w wypadku umieszczenia ramy w ,znaczącym” miejscu w kompozycji całości, gdy jej pojawienie się dla widza jest niespodzianką lub pojawia się ona często i w sposób nieuchwytny, wreszcie gdy ,zaciera granice między światem przedstawionym a realną, pozaartystyczną rzeczywistością"46.

Niezbadanych pozostaje wiele innych zabiegów, chwytów i rozwiązań narracyjnych, które w piśmiennictwie anglosaskim są często opisywane. $Z$ całą pewnością nie wymienię tu wszystkich, raczej wskażę kilka wybranych. Nieprzepracowana na gruncie polskim (brak więc opracowań teoretycznych, choć analitycznie samo pojęcie jest często wykorzystywane) została kategoria voice-

45 E. Biały, op. cit., s. 11.

46 T. Kłys, Ramy narracyjne jako chwyt poetyki negatywnej, w: M. Salska-Kaca (red.), Z problemów poetyki filmu, Wydawnictwo Uniwersytetu Łódzkiego, Łódź 1993, s. 37. Zob. także: idem, Poetyka negatywna w filmie. Zarys problematyki, „Studia Filmoznawcze” 1992, t. XIV: Film: symbol i tożsamość. 
-over ${ }^{47}$ jako wariant narracji werbalnej. Ciekawa byłaby próba nakreślenia relacji między narratorem mówiącym $z$ offu a jego obrazową reprezentacją, czyli postacią. Co z takimi przypadkami, gdy mamy więcej niż jednego narratora pozakadrowego (np. Kasyno Martina Scorsese), jak kształtują się relacje między nimi? Ujednolicenia i doprecyzowania wymaga wreszcie sama terminologia: kiedy mówimy o narracji z offu, a kiedy o voice-over? Ponadto czym charakteryzuje się narracyjny tryb przypuszczający w kinie, czym jest narracja kontrfaktyczna? Jakie zabiegi i chwyty stosowane są w celu zbudowania filmowej wypowiedzi warunkowej? O problemy te zahacza, ale w sposób niewystarczający, Waldemar Frąc w swojej książce Kino możliwe. Publikacja ta nie ma jednak charakteru opracowania narratologicznego ${ }^{48}$. Wreszcie w dobie remake'ów, sequeli, prequeli czy spin-offów istotna wydaje się kwestia narracyjnych i dramaturgicznych zbiegów umożliwiających seriali-

47 Problematyce tej poświęcona jest na przykład książka Sarah Kozloff. Zob. S. Kozloff, Invisible Storytellers: Voice-over in American Fiction Films, University of California Press, Berkley-Los Angeles-London 1988.

48 Wrąc pisze: „«Kino możliwe» objawia się również w utworach, które fundują nietypowy kształt samej struktury świata przedstawionego. Takie dzieło filmowe wyznacza wyraźnie dla niego granice, które następnie przekracza w możliwym wyobrażeniu. Odbiorca ma zatem do czynienia ze zwielokrotnieniem poziomów świata przedstawionego, a raczej odrębnymi bytowo uniwersami. Co więcej, tego rodzaju konstrukty cechuje znacząca otwartość, wyrażająca się w odrzuceniu typowej teleologii zdarzeń choćby poprzez odroczenie realizacji celu". W. Frąc, Kino możliwe, Rabid, Kraków 2003, s. 14. zację. Czy klasyczne już dziś cliffhangering endings wyczerpują możliwości otwierania się narracji na kontynuację opowieści? Last but not least, wystarczającej refleksji nie doczekały się także takie zagadnienia jak narracja retrospektywna i prospektywna.

\section{Narracja jako dominanta nurtów kina współczesnego}

Wskazane chwyty narracyjne, choć nieopracowane w książkach czy artykułach bezpośrednio im poświęconych, często pojawiają się jako kluczowe w tych pozycjach, które służą nakreśleniu charakterystyki konkretnych nurtów czy tendencji, zwłaszcza kina współczesnego. Bez wątpienia można stwierdzić, że rozwój kina ostatnich dwóch dekad związany jest $\mathrm{z}$ tworzeniem nowych paradygmatów narracyjnych i na nim się zasadza. Poświadcza to już książka Rafała Syski Filmowy neomodernizm, w której wstępie czytamy:

Świat definiuje dziś chaos doznań i niekończąca się konsumpcja, dystrakcja i odrętwienie, symulacja i prędkość, gadżetami dnia codziennego stają się urządzenia pozwalające na przyspieszenie i wymarzoną wszechobecność. Kino odpowiedziało na to dynamizmem filmowych atrakcji, przyspieszeniem tempa zdarzeń, szybkim montażem i agresywnym modelem narracji. Niekiedy nawet jedna ścieżka opowiadania nie jest wystarczająca i przekaz fabularny rozwarstwia się na serie konkurencyjnych kanałów komunikacji: zsynchronizowanych czasowo i przestrzennie. Dziś kontemplacja integralnego fabularnie dzieła, spójnego czasoprzestrzennie i logicznego w warstwie temporalnych związków, ustąpiła miejsca dystrakcji 
i dynamicznemu chłonięciu filmów jako mozaiki audiowizualnych atrakcji ${ }^{49}$.

Opisując kino neomodernistyczne, a więc slow-cinema, autor przeciwstawia jego sposób opowiadania narracji kina głównego nurtu. Oczywiście Syska nie omija kwestii charakterystycznych dla nurtu tematów, konstrukcji bohaterów czy związanego z nim kontekstu historycznego, produkcyjnego oraz spraw recepcji i dystrybucji, a nawet w tradycyjnej perspektywie autorskiej wskazuje na najważniejszych twórców nurtu. Jednak trudno nie odnieść wrażenia, że o odrębności i wyjątkowości dzieł neomodernistycznych przesądza specyfika rozwiązań narracyjno-dramaturgicznych, takich jak: brak następstwa zdarzeń, puenty, punktów kulminacyjnych, wreszcie czasowa rozciągłość, operowanie przestrzenią pozakadrową w budowaniu znaczeń, dyktat chronologii i jednowątkowości, pozorny obiektywizm i specyficzne podejście do narracyjnych schematów gatunkowych.

W jeszcze większej mierze na zagadnieniach związanych $\mathrm{z}$ narracją skupia się Barbara Szczekała, analizująca fenomen mind-game films. Ten aspekt poetyki zjawiska, o którym pisze, wybija już w podtytule swojej książki, brzmiącym Gry z narracja $i$ widzem ${ }^{50}$. Wybrzmiewa on także w pojęciu puzzle films, niekiedy stosowanym synonimicznie lub uważanym za kategorię pokrewną ${ }^{51}$. Kolejne części jej książki

\footnotetext{
R. Syska, Filmowy.., op. cit., s. 7-8.

B. Szczekała, Mind-game films..., op. cit.

W tym miejscu nie będę wikłała się w wyjaśnianie wzajemnych relacji między oboma terminami, bo czyni to wielu badaczy i jest to
}

pojęcie narracji przywołują jak mantrę. Kluczowy w tym aspekcie jest rozdział drugi (Ekscesy nagromadzenia $w$ mind-game films. Chwyty uniezwyklajace na poziomie narracji), w którym możemy przeczytać o takich charakterystycznych dla nurtu chwytach narracyjnych, jak: zwodniczość retrospekcji, (nie)porządek sekwencji, szkatułkowość i metalepsa, od-opowiedzenie oraz końcowy zwrot akcji i niewiarygodność narracji. Szczekała pisze o mind-game films jako o przejawie kina postklasycznego, dla którego charakterystyczne są ,(dys)komfort” oraz „dysnarratywia”. Nowe sposoby opowiadania wpływają więc na odbiór i zmieniają jego charakter. Wreszcie autorka książki wiąże popularność i rozkwit nurtu z transmedialnym wymiarem przemian narracji filmowej. Nad całością zaś unosi się duch kognitywistycznej narracji filmu jako zasadniczego punktu referencyjnego.

Książki Szczekały i Syski, pomimo ich „narratologicznej” orientacji, mają jednak znaczenie przede wszystkim jako pozycje diagnozujące ,stan” współczesnego filmu oraz próbujące uchwycić dominujące w nim tendencje. Nie rozwijają one narratologii jako takiej i nie stanowią w tym zakresie propozycji autorskich. Inaczej rzecz ma się w wypadku wydanych w 1998 roku Strategicznych dezorientacji Andrzeja Zalewskiego, w moim przekonaniu najbardziej orygi-

kwestia z punktu widzenia niniejszego artykułu drugorzędna. Warto na marginesie dodać, że inni badacze opisujący nurt także akcentują jego ,narracyjne” uwikłanie. Zob. np. W. Buckland, Puzzle Films: Complex Storytelling in Contemporary Cinema, Wiley-Blackwell, Oxford 2009. 
nalnej i najciekawszej pozycji poświęconej filmowemu postmodernizmowi. Zalewski definiuje go $\mathrm{z}$ chirurgiczną precyzją, nie jak inni badacze: poprzez zestaw cech z różnych porządków metodologicznych, ale konstruując (nie opisując czy referując!) charakterystyczny dlań paradygmat narracyjny i kontrastując go ze sposobem opowiadania kina modernistycznego. Już jego wstępne ustalenia (dookreślenie różnicy między technikami a strategiami oraz wyróżnienie rodzajów technik dezorientujących) są niezwykle użyteczne, i to nie tylko w odniesieniu do opisu kina postmodernistycznego. Z powodzeniem mogą być aplikowane do analizy wszelkiego rodzaju tekstów narracyjnych, zwłaszcza tych cechujących się niespójnością i prowadzących do dezorientacji. Zalewski idzie jednak o wiele dalej i wprowadza pojęcie ideizacji oraz różnych motywacji, które mogą jej dyktat podtrzymywać lub go rozbijać. W rezultacie wskazuje na wachlarz technik, które doprowadzają do - jak to ujmuje - „dewiacyjnych zmian” i różnego rodzaju „dysfunkcji” w motywowaniu. Jego finalne ustalenia nie mają charakteru redukcyjnego, nie sprowadza on kina postmodernistycznego do dezorientacji (przy wykorzystaniu odpowiednich technik), braku ideizacji i dysfunkcyjności na poziomie motywacji. W proponowanym ujęciu „Strategiczna dezorientacja w kinie ponowoczesno- ści jest [...] możliwa dzięki wielorakim zakłóceniom w procesie motywowania różnych składników diegezy [...]”, jednak ,chodzi nie tylko o odbieranie tezy, ale o jej sukcesywne zawieszanie i przywracanie, czyli o falowanie tetyczności [...]"52. Mimo upływu lat propozycja Zalewskiego, wyrastająca z fenomenologii, teorii aktów mowy Austina i oczywiście polemicznie czerpiąca z narratologii kognitywnej, wydaje się nadal intelektualnie atrakcyjna i nie traci na swej aktualności. Tym bardziej dziwi fakt jej znikomego wypływu na rodzimą choćby narratologię, co poniekąd wynika z hermetyczności języka, jakim posługuje się badacz.

Polska narratologia skorzystała na kognitywistycznym przełomie, jej stan dzisiejszy nie jest zatrważający, nie znajduję powodów do załamywania rąk i rwania włosów z głowy. Wręcz przeciwnie, z niecierpliwością oczekuję na kolejne książki z tego zakresu. Co więcej, wierzę, że niechybnie powstaną. Nie postuluję także rozwodu narratologii uprawianej na gruncie filmoznawstwa z jej literaturoznawczym zapleczem. Przed tym starym, dobrym małżeństwem zapewne jeszcze wiele kłótni, ale być może także kilka szczęśliwych chwil. Jeśli w polskiej narratologii istnieją czarne dziury, to nie obejmują one filmu fikcji, lecz kino niefikcjonalne, stanowiące prawdziwą terra incognita, ale i badawcze wyzwanie dla kolejnych filmoznawców.

A. Zalewski, Strategiczna dezorientacja..., op. cit., s. 167. 